\title{
Active transport of glucosylglycerol is involved in salt adaptation of the cyanobacterium Synechocystis sp. strain PCC 6803
}

\author{
Stefan Mikkat, Martin Hagemann and Arne Schoor
}

Author for correspondence: Stefan Mikkat. Tel: +49381494 2071. Fax: +493814942079.

Department of Biology, University of Rostock, 18051 Rostock, Germany

\begin{abstract}
An active-transport system for the osmoprotective compound glucosylglycerol (GG) was found in the cyanobacterium Synechocystis sp. strain PCC 6803. Uptake assays with ${ }^{14} \mathrm{C}$-labelled GG showed that the GG transport was enhanced in cells adapted to increasing concentrations of $\mathrm{NaCl}$. Kinetic studies indicated a Michaelis-Menten relationship. The uptake of GG was energy dependent and occurred against a steep concentration gradient. It was inhibited by uncouplers as well as by a combination of darkness and KCN. The affinity of the transporter seems to be restricted to osmoprotective compounds of cyanobacteria; from a variety of compounds tested only sucrose and trehalose competed with GG for uptake. A salt-sensitive mutant of Synechocystis 6803 unable to synthesize GG could be complemented to salt resistance by exogenous GG. Accumulation of GG from the medium was essential for the restoration of photosynthesis and growth in mutant cells under high-salt conditions. In wild-type cells, the GG transporter probably serves to prevent GG leaking out of salt-stressed cells.
\end{abstract}

Keywords: osmoprotective compound, glucosylglycerol transport, salt adaptation, cyanobacterium, Synechocystis sp.

\section{INTRODUCTION}

Salinity is an important abiotic factor in aquatic biotopes. Survival and growth in habitats with high or fluctuating salinities require prokaryotes to adjust their cytoplasmic water potential. Several archaebacteria and anaerobic heterotrophic eubacteria accumulate inorganic ions to maintain osmotic equilibrium with their surroundings. However, high concentrations of inorganic ions are toxic for most eubacteria. During adaptation to salt stress, these bacteria achieve a balanced osmotic potential by the extrusion of excess inorganic ions from the cell and the accumulation of osmoprotective compounds (compatible solutes). These low-molecular-mass hydrophilic compounds do not interfere with cell metabolism because they are largely inert and carry no net charge (Brown, 1976; Galinski \& Trüper, 1994). Besides reducing the osmotic potential of the cytoplasm, osmoprotective compounds apparently prevent denaturation by helping macromolecules to retain their natural configuration (e.g. Incharo-

Abbreviations: BV, biovolume; CCCP, carbonyl cyanide $m$ chlorophenylhydrazone; $D C C D, N, N^{\prime}$-dicyclohexylcarbodiimide; $D C M U, 3-$ (3,4-dichlorophenyl)-1,1-dimethylurea; 2,4-DNP, 2,4-dinitrophenol; FCCP, carbonyl cyanide $p$-(trifluoromethoxy)phenylhydrazone; GG, glucosylglycerol; MV, methyl viologen. ensadki et al., 1986). In salt-loaded cyanobacterial species, sucrose, trehalose, glucosylglycerol [2-O- $\alpha$-Dglucopyranosyl)-glycerol; GG], glycine betaine or glutamate betaine serve as the principal osmoprotective compounds (Reed \& Stewart, 1988). Cyanobacteria synthesize these substances de novo mainly from $\mathrm{CO}_{2}$ by photosynthesis, although limited amounts may be synthesized from stored glycogen or exogenous glucose (TelOr et al., 1986; Erdmann et al., 1989).

Unlike cyanobacteria, many heterotrophic eubacteria prefer to accumulate osmoprotective compounds from their environment. Several active-transport systems for the osmoprotective compounds proline, glycine betaine and its precursor choline have been characterized in a variety of bacteria, e.g. Escherichia coli, Salmonella typhimurium and Bacillus subtilis (Perroud \& Le Rudulier, 1985; Csonka \& Hanson, 1991; Boch et al., 1994). These systems are controlled by the osmolarity of the medium at the levels of both transport activity and gene expression (Lucht \& Bremer, 1994; Boch et al., 1994).

E. coli under osmotic stress is able to synthesize trehalose de novo, but if glycine betaine is available trehalose synthesis is completely repressed and adaptation to high osmotic pressure is achieved by accumulation of glycine betaine alone (Larsen et al., 1987; Giaever et al., 1988). A 
glycine betaine transport system has also been found in cyanobacteria. Interestingly, it was only present in strains which can synthesize this compound (Moore et al., 1987).

In the present study we have used the cyanobacterium Synechocystis sp. strain PCC 6803, which accumulates GG and tolerates up to $1.2 \mathrm{M} \mathrm{NaCl}$ (Reed \& Stewart, 1985). The osmoprotective compound GG is characteristic of moderately halotolerant cyanobacteria. It is synthesized from ADP-glucose and glycerol 3-phosphate by a saltactivated enzyme system (Hagemann \& Erdmann, 1994). We show here that Synechocystis 6803 has an active GG uptake system, which is involved in the process of salt adaptation.

\section{METHODS}

Organisms and culture conditions. Axenic cultures of Synechocystis sp. strain PCC 6803 were grown photoautotrophically under continuous illumination $\left(20 \mathrm{~W} \mathrm{~m}^{-2}\right)$ and bubbled with air containing $2.5 \%(\mathrm{v} / \mathrm{v}) \mathrm{CO}_{2}$ at $29^{\circ} \mathrm{C}$ in the growth medium of Allen \& Arnon (1955). The cells were inoculated into fresh medium daily. The basal medium contained $2 \mathrm{mM} \mathrm{NaCl}$. Cells grown at this $\mathrm{NaCl}$ concentration are hereafter referred to as control cells. To obtain salt-adapted cells, the cyanobacteria were precultured for at least $5 \mathrm{~d}$ in $\mathrm{NaCl}$-enriched medium. In salt-shock experiments solid $\mathrm{NaCl}$ was added to the cultures. To obtain hypo-osmotically treated cells, a culture adapted to $684 \mathrm{mM} \mathrm{NaCl}$ was harvested by centrifugation, and the cells were resuspended and cultivated for $2 \mathrm{~h}$ in basal medium. This procedure was repeated twice. The salt-sensitive mutant 107 (unpublished) of Synecbocystis 6803, which is unable to synthesize $\mathrm{GG}$, was cultivated in the presence of $25 \mu \mathrm{g} \mathrm{kanamycin} \mathrm{ml}^{-1}$. Methods for the generation and characterization of salt-sensitive mutants are described by Hagemann \& Zuther (1992). The purity of the cultures was checked by spreading $0.2 \mathrm{ml}$ culture onto LB plates and by microscopic examination.

Extraction and purification of GG. A culture of Synecbocystis 6803 (1 l ) adapted to $684 \mathrm{mM} \mathrm{NaCl}$ was harvested by centrifugation $\left(6000 \mathrm{~g}\right.$ at $4{ }^{\circ} \mathrm{C}$ for $\left.10 \mathrm{~min}\right)$ and stored at $-20^{\circ} \mathrm{C}$. GG was extracted from the cells with $200 \mathrm{ml} 80 \%(\mathrm{v} / \mathrm{v})$ ethanol for $3 \mathrm{~h}$ at $65^{\circ} \mathrm{C}$. After centrifugation at $6000 \mathrm{~g}\left(20^{\circ} \mathrm{C}\right.$ for $\left.15 \mathrm{~min}\right)$ the clear supernatant was evaporated in a rotary evaporator and redissolved in water. Insoluble particles (mainly pigments) were removed by centrifugation $\left(48000 \mathrm{~g}\right.$ at $4{ }^{\circ} \mathrm{C}$ for $30 \mathrm{~min}$ ). To remove charged compounds, the clear water extract was passed through ion-exchange resins. It was applied to a column of Dowex $50 \mathrm{Wx} 8\left(\mathrm{H}^{+}\right.$form), rinsed with water, and then passed through a column of Dowex $1 \times 2$ (formiat form). The effluent and rinse were collected, dried and again dissolved in water. These extracts were further purified by preparative TLC. TLC was performed in acetonitrile/water $(85: 15, \mathrm{v} / \mathrm{v}$, three runs) on self-coated plates (cellulose MN 300 , about $0.5 \mathrm{~mm}$ ). GG was scraped off, eluted with water, and dried. The purity of the extracted GG was about $98 \%$ as determined by HPLC.

Preparation of ${ }^{14} \mathrm{C}$-labelled GG. A culture of Synechocystis 6803 $(500 \mathrm{ml})$ adapted to $342 \mathrm{mM} \mathrm{NaCl}$ was shocked by adding $10 \mathrm{~g}$ $\mathrm{NaCl}$ (final $\mathrm{NaCl}$ concentration $684 \mathrm{mM}$ ) to achieve an inhibition of growth and specific activation of GG synthesis. These cells were incubated with $11 \cdot 1 \mathrm{MBq} \mathrm{NaH}{ }^{14} \mathrm{CO}_{3}$ (specific activity $1670 \mathrm{MBq} \mathrm{mmol}^{-1}$ ) for $5 \mathrm{~h}$ without gassing. The cells were harvested by centrifugation $\left(6000 \mathrm{~g}\right.$ at $4^{\circ} \mathrm{C}$ for $\left.10 \mathrm{~min}\right)$, washed twice, and $\left[{ }^{14} \mathrm{C}\right] \mathrm{GG}$ was extracted as described above. The purity of the labelled GG was checked by two-dimensional TLC (Feige et al., 1969). After detection of labelled compounds by autoradiography, only one spot at the position of authentic $\mathrm{GG}$ was visible. For the determination of the specific activity of the $\left[{ }^{14} \mathrm{C}\right] \mathrm{GG}$, the amount of $\mathrm{GG}$ was estimated after acid hydrolysis using an enzymic glucose assay (Erdmann et al., 1992).

Transport assays. Two $\left[{ }^{14} \mathrm{C}\right] \mathrm{GG}$ preparations with specific activities of 0.954 d.p.m. pmol ${ }^{-1}$ and 0.659 d.p.m. pmol ${ }^{-1}$, respectively, were used. $\left[\mathrm{U}^{14} \mathrm{C}\right]$ sucrose (specific activity $25 \mathrm{GBq}$ $\mathrm{mmol}^{-1}$, Amersham) was purified from glucose and fructose by TLC on silica gel 60 plates (Merck) developed in acetone/ water/chloroform/methanol (75:5:10:10, by vol., two runs). Uptake was measured under the culture conditions described above without gassing. The cell suspension $(0.5 \mathrm{ml})$ was directly taken from the cultures [biovolume (BV) $1 \cdot 8-2 \cdot 8 \mathrm{~mm}^{3} \mathrm{ml}^{-1}$ ] and incubated for $15 \mathrm{~min}$ with an appropriate amount of $\left[{ }^{14} \mathrm{C}\right] \mathrm{GG}$ or $\left[\mathrm{U}-{ }^{14} \mathrm{C}\right]$ sucrose. The tests were stopped by adding $3 \mathrm{ml}$ of medium of the same salt concentration and immediate filtration through membrane filters $(0.45 \mu \mathrm{m}$, SM 11306, Sartorius). Subsequently, the filters were washed three times with $3 \mathrm{ml}$ cultivation medium and solubilized in a scintillation cocktail [toluene/Triton X-100 (2:1, v/v), 0.4\% PPO, 0.012\% dimethyl-POPOP]. Radioactivity was determined by liquid scintillation counting. Modifications of this standard assay are described in the text.

Kinetic parameters were analysed using the EKI software (Raddatz, 1994). All values derive from Lineweaver-Burk plots based on the weighting method of Wilkinson (1961). Data for $K_{\mathrm{m}}$ and $V_{\max }$ are given as mean values $\pm \mathrm{sD}$ from at least three determinations performed with independent cultures.

Complementation of mutant 107. Cells of the salt-sensitive mutant 107 grown at $87 \mathrm{mM} \mathrm{NaCl}$ were shocked by additional $513 \mathrm{mM} \mathrm{NaCl}$ (final concentration $600 \mathrm{mM} \mathrm{NaCl}$ ). GG was provided at a concentration of $0.75 \mathrm{mM}$. After the times indicated samples were harvested by centrifugation and washed twice with medium of the same salt concentration.

Other methods. The GG content was estimated after extraction in $80 \%$ ethanol by HPLC (Schoor et al., 1995). Cell number and diameter were determined by means of an electronic particle counter (Erdmann et al., 1992). Fixation of the cells by Lugol solution led to shrinkage. Therefore the BV (product of cell number and cell volume) was underestimated by about $15 \%$. $\mathrm{OD}_{750}$ was measured using a Spekol 11 instrument (Carl Zeiss Jena). Dry mass was estimated using membrane filters $(0 \cdot 2 \mu \mathrm{m}$, SM 11107, Sartorius). Total protein was determined by the Lowry method after suspending the cells in $1 \mathrm{M} \mathrm{NaOH}$, ultrasonic treatment $(90 \mathrm{~s}$ at $30 \mathrm{~W})$, and hydrolysis at $37^{\circ} \mathrm{C}$ overnight. In this study BV was used as the parameter for biomass. To allow comparison with other uptake studies, the different biomass parameters were correlated to each other. For cells of Synechocystis 6803 from basal medium a BV of $1 \mathrm{~mm}^{3}$ $\mathrm{ml}^{-1}$ is equivalent to a protein content of $240 \mu \mathrm{g} \mathrm{ml}^{-1}$, a dry mass of $415 \mu \mathrm{g} \mathrm{ml}^{-1}$, and an $\mathrm{OD}_{750}$ of 1.09. For cells of Synechocystis 6803 adapted to $684 \mathrm{mM} \mathrm{NaCl}$, a BV of $1 \mathrm{~mm}^{3} \mathrm{ml}^{-1}$ is equivalent to a protein content of $216 \mu \mathrm{g} \mathrm{m}^{-1}$, a dry mass of $458 \mu \mathrm{g} \mathrm{ml}^{-1}$, and an $\mathrm{OD}_{750}$ of 0.89 . Photosynthesis and respiration were determined polarographically using a Clark-type oxygen electrode (Erdmann et al., 1992).

\section{RESULTS}

\section{Evidence for GG uptake}

Cells of Synecbocystis 6803 were able to accumulate $\left[{ }^{14} \mathrm{C}\right] \mathrm{GG}$. The rate of GG uptake was substantially higher in salt-adapted than in control cells (Fig. 1); it was linear 


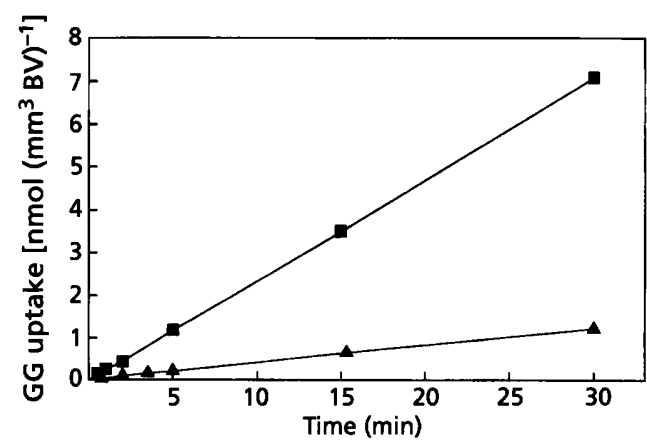

Fig. 1. Time course of GG uptake by Synechocystis 6803 . Suspensions of photoautotrophically grown cells were incubated in the light $\left(20 \mathrm{~W} \mathrm{~m}^{-2}\right)$ at $29^{\circ} \mathrm{C}$ in growth medium containing $1 \mathrm{mM}\left[{ }^{14} \mathrm{C}\right] \mathrm{GG}$. Cells were adapted to $2 \mathrm{mM} \mathrm{NaCl}(\boldsymbol{A})$ or $684 \mathrm{mM} \mathrm{NaCl}(\mathbf{\square})$.

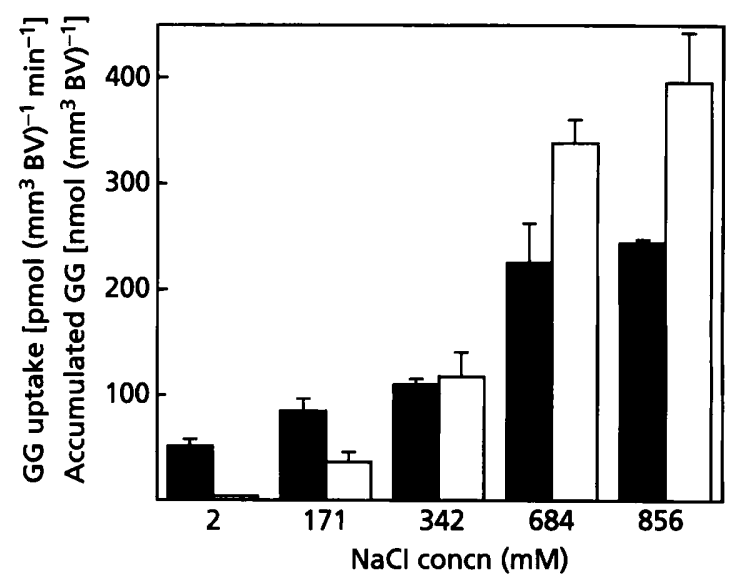

Fig. 2. Effect of adaptation of Synechocystis 6803 to different $\mathrm{NaCl}$ concentrations on the rate of GG uptake and on the intracellular accumulation of GG. Uptake was determined with a $\left[{ }^{14} \mathrm{C}\right] \mathrm{GG}$ concentration of $1 \mathrm{mM}$ using the standard assay (filled bars). The concentrations of accumulated GG was estimated by HPLC (open bars). Cells were adapted to the indicated salinities for at least $5 \mathrm{~d}$. Data are mean values $\pm S D$ from determinations performed with independent cultures. The number of determinations (in sequence of increasing $\mathrm{NaCl}$ concentrations) was 9, 4, 4, 8 and 2 for GG uptake, and 3, 4, 4, 4 and 2 for $G G$ accumulation.

for at least $30 \mathrm{~min}$. Therefore, we used an incubation time of 15 min to measure the initial velocities of GG transport in the standard assays. TLC of ethanolic extracts of control and salt-adapted cells incubated for $30 \mathrm{~min}$ with $\left[{ }^{14} \mathrm{C}\right] \mathrm{GG}$ showed a single ${ }^{14} \mathrm{C}$-labelled compound, which co-chromatographed with authentic GG. This indicates that the exogenous GG taken up by the cells was not metabolized (not shown).

GG transport in cells adapted to different salt concentrations was investigated. Increasing transport activity was found in cells grown in medium containing increasing amounts of $\mathrm{NaCl}$ (Fig. 2). Cells adapted to $856 \mathrm{mM} \mathrm{NaCl}$ showed a fivefold higher uptake rate than control cells. In

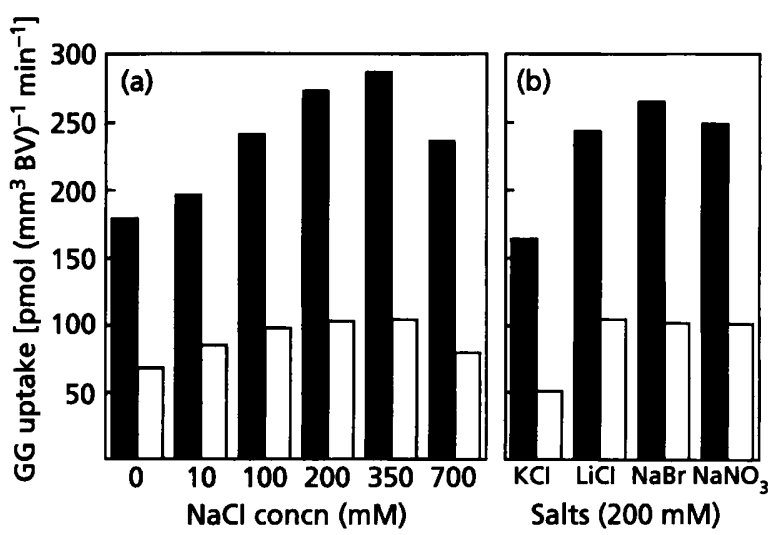

Fig. 3. Effect of short-term changes of the salinity on the GG uptake by Synechocystis 6803 . Cells were washed and resuspended in a buffer solution containing $20 \mathrm{mM}$ MOPS/KOH (pH 7.5), $0.5 \mathrm{mM} \mathrm{MgSO}_{4}$ and $0.5 \mathrm{mM} \mathrm{CaCl}_{2}$. Different concentrations of $\mathrm{NaCl}(\mathrm{a})$ or different salts at a concentration of $200 \mathrm{mM}$ (b) were added before the uptake reaction was started by addition of $\left[{ }^{14} \mathrm{C}\right] \mathrm{GG}(0.2 \mathrm{mM})$. The control (without added salt) for (b) is the same as in (a). Control cells (open bars) and hypo-osmotically treated cells prepared as described in Methods (filled bars) were used.

salt-adapted cells GG was synthesized de novo and accumulated to concentrations corresponding to the external salinity (Fig. 2). Therefore, the GG uptake took place against a steep concentration gradient.

\section{Modulation of GG uptake by salinity}

To test whether the enhanced transport activity of saltadapted cells was due to a salt-dependent activation of pre-existing transporter molecules or to their de novo synthesis following an increase in salinity, GG uptake was measured after different shock treatments. If control cells were shocked with $684 \mathrm{mM} \mathrm{NaCl}$, the uptake rate remained nearly unaltered for at least $5 \mathrm{~h}$. Twenty-four hours after the shock treatment a two- to threefold increase was noticed in different experiments, while completely adapted cells took up GG about fourfold faster than control cells. In contrast, a shock of only $342 \mathrm{mM}$ $\mathrm{NaCl}$ was followed by a shorter lag period, and the final uptake rate was reached after $24 \mathrm{~h}$ (data not shown). In inverse experiments, cells adapted to $684 \mathrm{mM} \mathrm{NaCl}$ were hypo-osmotically shocked using basal medium. In this case, the GG uptake remained at the high rate of saltadapted cells for at least $5 \mathrm{~h}$ (data not shown). Therefore, the differences in GG uptake rates of control and saltadapted cells, respectively, were the result of a long-term adaptation process including de novo synthesis of protein.

However, if hypo-osmotically treated cells were washed and resuspended in a buffer solution containing only traces of additional ions, the GG transport was immediately influenced by the addition of salts into the uptake assays (Fig. 3). The uptake rate was enhanced by increasing $\mathrm{NaCl}$ concentrations between 10 and $350 \mathrm{mM}$, while $700 \mathrm{mM} \mathrm{NaCl}$ led to some inhibition compared to 
the optimal activation at $350 \mathrm{mM} \mathrm{NaCl}$ (Fig. 3a). Additions of $\mathrm{NaBr}, \mathrm{NaNO}_{3}$ and $\mathrm{LiCl}$ had about the same effect as $\mathrm{NaCl}$, while $\mathrm{KCl}$ at a concentration of $200 \mathrm{mM}$ was somewhat inhibitory (Fig. 3b). The same situation was found if control cells were washed and resuspended in buffer solution (Fig. 3). To exclude protein synthesis, chloramphenicol $\left(40 \mu \mathrm{g} \mathrm{ml}^{-1}, 10\right.$ min preincubation time; Hagemann et al., 1990) was used. This treatment did not affect the activation of GG uptake by short-term changes of the salinity (data not shown). These data imply that an increase of the $\mathrm{NaCl}$ concentration is responsible for both de novo synthesis of transporter proteins in a long-term process and, to a lesser degree, immediate activation of pre-existing transporters.

The GG uptake system was not inducible by GG, since incubation of control cells with $1 \mathrm{mM} \mathrm{GG}$ for 24 or $72 \mathrm{~h}$ did not increase the transport activity (data not shown).

\section{Kinetics of GG transport}

The kinetics of GG uptake in Synecbocystis 6803 were studied in salt-adapted and control cells at various exogenous GG concentrations. Uptake of $10-4000 \mu \mathrm{M}$ GG followed a typical Michaelis-Menten relationship (data not shown). The maximum velocity of substrate uptake was substantially higher in cells adapted to $684 \mathrm{mM} \mathrm{NaCl}$ than in control cells $(269 \pm 59$ and $48 \pm$ $6 \mathrm{pmol}\left(\mathrm{mm}^{3} \mathrm{BV}\right)^{-1} \mathrm{~min}^{-1}$, respectively), as was expected from the transport experiments using cells adapted to different salinities (see Fig. 2). The apparent substrate affinity was also affected by the salinity; $K_{\mathrm{m}}$ values of $124 \pm 17$ and $52 \pm 13 \mu \mathrm{M}$ were estimated for cells adapted to 684 and $2 \mathrm{mM}$ (control cells) $\mathrm{NaCl}$, respectively. Beside the rather unlikely possibility of a decreased affinity for GG in salt-adapted cells, another explanation for this difference could be the leakage of intracellular GG into the medium or the periplasm. This leakage would increase the periplasmic GG concentration and decrease the specific activity of the exogenous $\left[{ }^{14} \mathrm{C}\right] \mathrm{GG}$, leading therefore to the apparently reduced affinity. Leakage of the osmoprotective compound trehalose into the periplasm has been reported for E. coli (Styrvold \& Strøm, 1991).

To differentiate between these two possibilities, kinetics of GG uptake were measured using washed and hypoosmotically treated cells, respectively. Salt-adapted cells were washed with fresh medium of the same $\mathrm{NaCl}$ content to remove $\mathrm{GG}$ possibly present in the cultivation medium. This treatment did not reduce the apparent $K_{\mathrm{m}}$. In accordance with this result, GG was not found in the medium by HPLC analysis. Hypo-osmotic treatment is supposed to completely remove GG accumulated in the cytoplasmic and periplasmic space (Reed et al., 1986; Fulda et al., 1990). Therefore, hypo-osmotically-treated cells were prepared as described in Methods. The treatment reduced the intracellular GG content to $3.5 \mathrm{nmol}$ $\left(\mathrm{mm}^{3} \mathrm{BV}\right)^{-1}$, a level comparable to that observed in control cells. After continued cultivation for $2 \mathrm{~h}$ in medium containing $684 \mathrm{mM} \mathrm{NaCl}$, these cells showed a $K_{\mathrm{m}}$ value of $58 \mu \mathrm{M}$, comparable to control cells. Therefore, the high
Table 1. Effect of metabolic inhibitors and incubation in the dark on the uptake of GG by Synechocystis 6803

Cells adapted to $684 \mathrm{mM} \mathrm{NaCl}$ were preincubated with inhibitors or in darkness for $15 \mathrm{~min}$ before the uptake reaction (standard assay) was started by adding $\left[{ }^{14} \mathrm{C}\right] \mathrm{GG}(0.2 \mathrm{mM})$. Values are given as a percentage of GG uptake under the indicated treatments, compared to controls. If ethanol was used as solvent for the inhibitors, values were corrected for the effect of ethanol. Data are mean values $\pm \mathrm{sD}$. The number of experiments performed with independent cultures is indicated in parentheses.

\begin{tabular}{|lrlr|}
\hline Treatment & Concn & $\begin{array}{l}\text { GG uptake } \\
\text { (\% of control) }\end{array}$ \\
\hline CCCP & $25 \mu \mathrm{M}$ & $54 \pm 8(4)$ \\
CCCP & $100 \mu \mathrm{M}$ & 21 & $(1)$ \\
FCCP & $25 \mu \mathrm{M}$ & $45 \pm 5(4)$ \\
FCCP & $100 \mu \mathrm{M}$ & 20 & $(2)$ \\
DCCD & $100 \mu \mathrm{M}$ & $95 \pm 3(3)$ \\
Orthovanadate & $100 \mu \mathrm{M}$ & 97 & $(1)$ \\
DCMU & $10 \mu \mathrm{M}$ & $81 \pm 5(4)$ \\
DCMU & $50 \mu \mathrm{M}$ & 73 & $(1)$ \\
$2,4-\mathrm{DNP}$ & $1 \mathrm{mM}$ & $76 \pm 6(3)$ \\
KCN & $1 \mathrm{mM}$ & $96 \pm 14(7)$ \\
MV & $1 \mathrm{mM}$ & 88 & $(2)$ \\
Darkness & & $77 \pm 12(5)$ \\
Darkness $+\mathrm{KCN}$ & $1 \mathrm{mM}$ & $14 \pm 2(5)$ \\
MV+KCN & each $1 \mathrm{mM}$ & 51 & $(2)$ \\
DCMU + KCN & $10 \mu \mathrm{M} / 1 \mathrm{mM}$ & $88 \pm 7(3)$ \\
\hline
\end{tabular}

apparent $K_{\mathrm{m}}$ value estimated for salt-adapted cells was related to the high GG content of these cells. Probably leakage of GG into the periplasm caused overestimation of the $K_{\mathrm{m}}$ in untreated cells adapted to $684 \mathrm{mM} \mathrm{NaCl}$.

\section{Effects of pH and metabolic inhibitors on the GG transport}

GG uptake was also studied at various $\mathrm{pH}$ values. Acid $\mathrm{pH}$ inhibited GG uptake in salt-adapted cells of Synechocystis 6803. A linear increase in transport activity was observed between $\mathrm{pH} 4$ and 7 , while it remained unchanged at $\mathrm{pH}$ values above $7 \cdot 5$ (data not shown).

Several inhibitors and incubation in the light and dark were used to analyse the energetic basis of the GG uptake in salt-adapted cells of Synechocystis 6803 (Table 1). Addition to a final concentration of $25 \mu \mathrm{M} \mathrm{CCCP}$ or FCCP, which uncouple phosphorylation from photosynthetic and respiratory electron transport, diminished GG uptake by about $50 \%$; very high uncoupler concentrations $(100 \mu \mathrm{M})$ inhibited uptake by $80 \%$. Transport was not affected by DCCD or orthovanadate, inhibitors of $\mathrm{H}^{+}$-ATPases localized in the cytoplasmic membrane, or by $\mathrm{KCN}$, an inhibitor of cytochrome oxidase. Treatments which inhibit photosynthesis [addition of DCMU, MV, darkness] showed only minor effects on GG transport. A combination of darkness and $\mathrm{KCN}$ led to about $85 \%$ inhibition, which is comparable with the effects of the uncouplers. A combined treatment with MV (competes 
Table 2. Effect of various compounds on the uptake of GG by Synechocystis 6803

Cells adapted to 684 or $2 \mathrm{mM}$ (control cells) $\mathrm{NaCl}$ were incubated as described for the standard assay with $\left[{ }^{14} \mathrm{C}\right] \mathrm{GG}$ $(0.2 \mathrm{mM})$ in the presence of the unlabelled compounds $(2 \mathrm{mM})$. Values are given as a percentage of GG uptake, compared to controls without supplements. Data are mean values $\pm \mathrm{sD}$. The number of experiments performed with independent cultures is indicated in parentheses. ND, Not determined.

\begin{tabular}{|c|c|c|}
\hline \multirow[t]{2}{*}{ Compound } & \multicolumn{2}{|c|}{ GG uptake ( $\%$ of control) } \\
\hline & Salt-adapted cells & Control cells \\
\hline GG & $22 \pm 2$ & $16 \pm 5(3)$ \\
\hline Sucrose & $28 \pm 5$ & $19 \pm 5(3)$ \\
\hline Trehalose & $61 \pm 4$ & $53 \pm 7(3)$ \\
\hline Maltose & $102 \pm 4$ & $104 \quad(1)$ \\
\hline Methyl $\alpha$-D-glucoside & $101 \pm 6$ & ND \\
\hline Phenyl $\alpha$-D-glucoside & $93 \pm 4$ & $93 \quad(1)$ \\
\hline Floridoside & $98 \quad(2)$ & 101 \\
\hline Raffinose & $99 \pm 12(4)$ & 102 \\
\hline Glucose & $96 \pm 4$ & $89 \quad(1)$ \\
\hline Fructose & $100 \pm 5$ & ND \\
\hline Glycerol & $97 \quad(2)$ & ND \\
\hline
\end{tabular}

with cyclic photosynthetic electron transport) and $\mathrm{KCN}$ causes intermediate inhibition of about $50 \%$, while the combination of DCMU (blocks non-cyclic photosynthetic electron transport) and $\mathrm{KCN}$ had almost no effect (Table 1).

\section{Specificity of the GG transporter}

In order to study the specificity of the GG transport, various unlabelled potential competitors were used in 10fold excess (Table 2). Transport was not affected by the monosaccharides glucose or fructose, nor by phenyl or methyl glucosides. The structural analogue floridoside (galactosylglycerol), an osmoprotective compound of red algae (Kirst, 1990), showed no interference with the GG uptake. However, the disaccharide sucrose inhibited the transport of $\left[{ }^{14} \mathrm{C}\right] \mathrm{GG}$ to nearly the same extent as unlabelled GG, indicating a similar affinity of the transporter for these two compounds. To a lesser extent trehalose also diminished the GG transport. The somewhat lower inhibition by unlabelled GG, sucrose or trehalose of GG uptake in salt-adapted cells compared to control cells is consistent with the apparently reduced affinity for GG in salt-adapted cells. The disaccharide maltose and raffinose (a trisaccharide consisting of a sucrose molecule bound by an $\alpha-1,6$-glycosidic bond to galactose) did not affect GG uptake (Table 2).

Cells of Synechocystis 6803 took up $\left[\mathrm{U}^{14} \mathrm{C}\right]$ sucrose, and the time course and rates of uptake with cultures adapted to 2 or $684 \mathrm{mM} \mathrm{NaCl}$ were similar to those for $\mathrm{GG}$ uptake (data not shown). With control cells, measurements of sucrose uptake at various exogenous sucrose concen-
Table 3. Kinetic parameters for competition of GG, sucrose and trehalose for uptake by Synechocystis 6803

Kinetics of GG and sucrose uptake were studied with cells adapted to $2 \mathrm{mM} \mathrm{NaCl}$ at various exogenous substrate concentrations ranging from 15 to $960 \mu \mathrm{M}$ in the absence or presence of competitive inhibitors. For GG uptake, inhibitor concentrations of 100 and $500 \mu \mathrm{M}$ sucrose and $500 \mu \mathrm{M}$ trehalose were used. For sucrose uptake, GG was added at 100 and $500 \mu \mathrm{M}$ and trehalose at $500 \mu \mathrm{M}$. Data were analysed as described in Methods. $V_{\max } \pm \mathrm{sD}$ from the determinations with and without inhibitors was $52 \pm 4$ and $45 \pm 2 \mathrm{pmol}\left(\mathrm{mm}^{3} \mathrm{BV}\right)^{-1} \mathrm{~min}^{-1}$ for GG and sucrose uptake, respectively. Values for $K_{\mathrm{m}}$ and $K_{\mathrm{i}}$ are given in $\mu \mathrm{M}$.

\begin{tabular}{|lcc|}
\hline Parameter & GG uptake & Sucrose uptake \\
\hline$K_{\mathrm{m}}$ & 52 & 120 \\
$K_{\mathrm{i}}$ (GG) & - & 77 \\
$K_{\mathrm{i}}$ (sucrose) & 96 & - \\
$K_{\mathrm{i}}$ (trehalose) & 332 & 298 \\
\hline
\end{tabular}

trations ranging from 15 to $960 \mu \mathrm{M}$ gave the following kinetic parameters: $K_{\mathrm{m}}=106 \pm 12 \mu \mathrm{M}, V_{\max }=51 \pm 7$ pmol $\left(\mathrm{mm}^{3} \mathrm{BV}\right)^{-1} \mathrm{~min}^{-1}$. In the presence of $\mathrm{GG}$ or trehalose at concentrations 10 times that of sucrose, the sucrose uptake was inhibited $88 \%$ or $67 \%$, respectively.

The kinetics of GG and sucrose uptake were studied in the absence and presence of the inhibitory compounds (Table 3). Their addition did not decrease $V_{\max }$, while the $K_{\mathrm{m}}$ values were apparently increased. These results clearly indicate the competitive nature of inhibition. From the increased $K_{\mathrm{m}}$ values the inhibitor constants $\left(K_{\mathrm{i}}\right)$ were estimated. The inhibitor constants for GG and sucrose were in good coincidence with the corresponding $K_{\mathrm{m}}$ values for these compounds (Table 3).

\section{Complementation of the salt-sensitive mutant 107 by exogenously supplied GG}

Mutant 107 of Synechocystis 6803 has a salt resistance limit at about $0.5 \mathrm{M} \mathrm{NaCl}$ (about $40 \%$ of the wild-type) caused by a defect in GG synthesis. Preliminary experiments showed that the ability to transport GG remained intact and mutant 107 grew like the wild-type in basal medium. Therefore, the mutant 107 was chosen to test whether the GG transport activity is sufficient for the accumulation of high amounts of GG to compensate a lethal salt shock. Cells of mutant 107 were shocked with $513 \mathrm{mM} \mathrm{NaCl}$ (final concentration $600 \mathrm{mM} \mathrm{NaCl}$ ) in the presence or absence of $0.75 \mathrm{mM} \mathrm{GG}$ in the medium. The salt shock led to a substantial drop in photosynthetic $\mathrm{O}_{2}$ production (Fig. 4a). In absence of GG, photosynthesis was completely inhibited after $24 \mathrm{~h}$. No regeneration of photosynthesis, no growth and no accumulation of GG could be observed during the $96 \mathrm{~h}$ of the experiment. In cultures of mutant 107 supplemented with GG, photosynthetic activity started to increase about $24 \mathrm{~h}$ after the salt shock. At the same time significant amounts of GG were already 


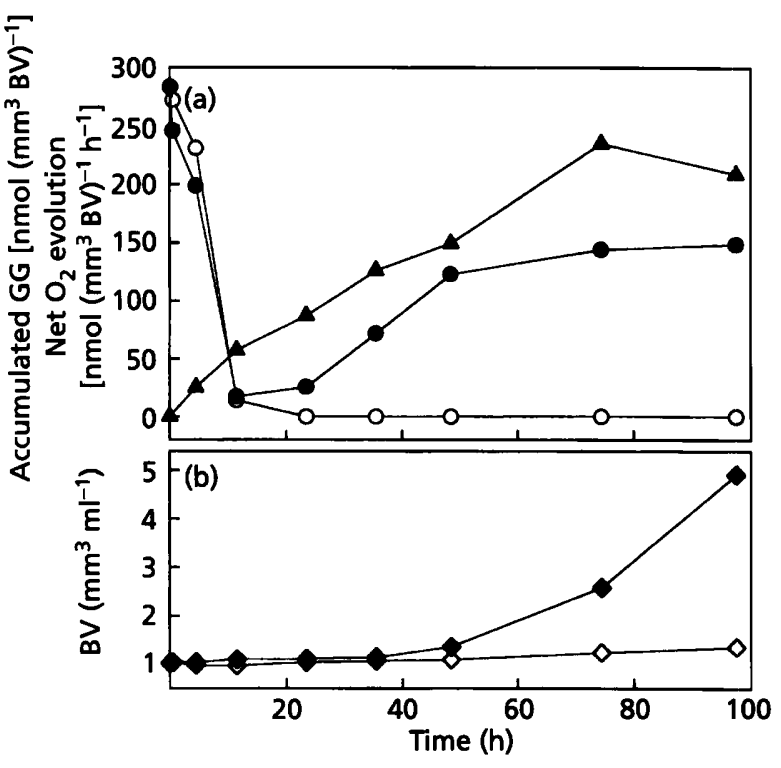

Fig. 4. Effect of exogenously supplied GG on mutant 107 after a salt shock. This mutant of Synechocystis 6803 is unable to synthesize GG and is consequently salt sensitive. It was subjected to a salt shock in the presence (filled symbols) or absence (open symbols) of external GG, as described in Methods. (a) GG concentration in cells grown in the presence of $0.75 \mathrm{mMGG}$ ( $A$ ) and photosynthesis, measured as net $\mathrm{O}_{2}$ evolution, of cells grown with $0.75 \mathrm{mM} \mathrm{GG} \mathrm{(O)}$ and without added GG (O), respectively. (b) Growth expressed as increase of biovolume of the culture with $0.75 \mathrm{mM} \mathrm{GG}(\diamond)$ and without added GG $(\diamond)$, respectively.

detectable in the cells (Fig. 4a). Between 36 and $48 \mathrm{~h}$ after the salt shock, cultures supplemented with GG started to grow again (Fig. 4b) and photosynthetic $\mathrm{O}_{2}$ production reached about $50 \%$ of the initial level (Fig. 4 a).

\section{DISCUSSION}

The studies presented here demonstrate the existence of an active-transport system for exogenous GG in the cyanobacterium Synechocystis 6803. The following results are evidence for the active nature of GG uptake: ${ }^{14} \mathrm{C}$ labelled GG was transported into salt-adapted cells containing GG in high concentrations against a remarkable concentration gradient; the same concentration gradient was established in a mutant which is unable to synthesize GG (in this case by means of the transport system); and furthermore, the inhibition of energy supply (by incubation under darkness and in the presence of specific inhibitors) decreased GG uptake substantially and indicated its dependence on metabolic energy.

Because of their primary photoautotrophic growth mode, little information is available on the transport of sugars and related compounds by cyanobacteria. However, Synechocystis 6803 does possess an active-transport system for glucose (Flores \& Schmetterer, 1986; Joset et al., 1988). Therefore, exogenous GG could be hydrolysed outside the cell followed by uptake of glucose and glycerol. The latter might enter the cell by passive diffusion. In $E$. coli, where trehalose is used as an osmoprotective compound, utilization of exogenous trehalose under conditions of high osmolarity takes place by hydrolysis to glucose and subsequent uptake via the phosphoenolpyruvate:sugar phosphotransferase system (Boos et al., 1990). Since glucose did not interfere with GG uptake in Synechocystis 6803, hydrolysis of GG and subsequent uptake of glucose can be excluded. Furthermore, separation by TLC of ethanolic extracts of cells incubated with $\left[{ }^{14} \mathrm{C}\right] \mathrm{GG}$ indicate that $\mathrm{GG}$ entered the cells unaltered. It was not metabolized in control or in saltadapted cells, indicating that GG showed no turnover. The absence of a GG turnover was also postulated for salt-adapted cells of the cyanobacterium Microcystis firma (Hagemann et al., 1987).

The transport system for GG seems to be involved in the process of salt adaptation because its activity corresponded with the external salt concentration. Compared to other processes involved in salt adaptation of Synechocystis 6803 (Erdmann et al., 1992), the increased level of GG transport activity was reached after a rather long time following a salt shock of $684 \mathrm{mM} \mathrm{NaCl}$. After hypoosmotic shock it remained at the high level of salt-adapted cells for several hours. Changes of the activity of GG uptake probably represent both increased and decreased amounts of transporter protein in response to the salinity of the growth medium. Therefore, the protein(s) of this transport system seemed to have a slow turnover rate. In addition to the enhanced synthesis, the GG uptake system was activated by increasing $\mathrm{NaCl}$ concentrations up to $350 \mathrm{mM}$. However, activation did not increase the transport rate by more than $50 \%$. The GG-synthesizing enzyme system was more affected by short-term changes of the salinity (Hagemann \& Erdmann, 1994). Summarizing, the GG transport system seems to be regulated by the salinity at the level of both gene expression and, to a lesser degree, activity of pre-existing transport proteins.

The kinetics of the GG transporter are characteristic of bacterial uptake systems, which involve specific transport proteins. The estimated $K_{\mathrm{m}}$ value of about $50 \mu \mathrm{M}$ is comparable to values of the sugar uptake systems in several cyanobacterial strains, which generally exhibit weak affinities (between 100 and $1400 \mu \mathrm{M}$; Smith \& Moore, 1988; Joset et al., 1988; Schmetterer \& Flores, 1988). In contrast, the glycine betaine transporter of the cyanobacterium Aphanothece balophytica exhibited a higher affinity for its substrate $\left(K_{\mathrm{m}} 2 \mu \mathrm{M}\right.$; Moore et al., 1987). Furthermore, this transport system showed about a 170fold higher $V_{\max }$ than the GG transporter of Synecbocystis 6803.

The energy dependence of the GG uptake was confirmed by the inhibitory effects of the uncouplers CCCP and FCCP in the light, as well as by $\mathrm{KCN}$ in the dark. $\mathrm{KCN}$ was ineffective in the light, and incubation in the dark without this inhibitor diminished GG uptake only slightly. Inhibition of both photosynthetic and respiratory electron transport (by the combination of darkness and $\mathrm{KCN}$ ) or their uncoupling from phosphorylation (by CCCP or FCCP) was necessary to inhibit the GG 
transport. Therefore, both processes can provide energy for uptake. It should be noted that in cyanobacteria the respiratory and photosynthetic electron transport chains are closely linked by sharing plastoquinone and cytochrome $b_{6} f$ (e.g. Mi et al., 1994). No conclusions concerning the mechanism of GG transport could be drawn from the inhibitor data.

The competition experiments indicated that sucrose is accepted by the GG transport system with a somewhat lower affinity. This was confirmed by uptake experiments with $\left[\mathrm{U}^{14} \mathrm{C}\right]$ sucrose. Using control cells, uptake showed about the same $V_{\max }$ as for GG, but the $K_{\mathrm{m}}$ value was doubled compared to GG. To a lesser extent trehalose also seems to be transported by this system, since both GG and sucrose uptake were competitively inhibited by trehalose. The inhibitor constants for GG, sucrose and trehalose together with the $K_{\mathrm{m}}$ values for GG and sucrose confirm that the transport system displays the highest affinity towards GG, about half this affinity for sucrose, and a substantially lower affinity for trehalose. Surprisingly, floridoside, which is structurally closely related to GG, and all other compounds tested did not compete in uptake experiments. Interestingly, the transport system showed affinity only to substances (GG, sucrose, and trehalose) used as osmoprotective compounds by cyanobacteria. E. coli is also able to take up different osmolytes using its ProU and ProP systems (Csonka \& Hanson, 1991; Lucht \& Bremer, 1994).

The rather low activity of the GG transport was sufficient for the adaptation of the salt-sensitive mutant 107 of Synechocystis 6803 to a lethal salt concentration of $600 \mathrm{mM}$ $\mathrm{NaCl}$ in the presence of $0.75 \mathrm{mM}$ exogenously supplied GG. In the absence of GG, salt adaptation was not possible. The cells needed about $75 \mathrm{~h}$ to accumulate GG in concentrations comparable to the amount contained by wild-type cells at this salinity. De novo synthesis of GG in the wild-type strain reached a final value $12 \mathrm{~h}$ after a salt shock of $684 \mathrm{mM} \mathrm{NaCl}$. The complementation of mutant 107 to salt tolerance by adding GG provides for the first time direct evidence that accumulation of GG is osmoprotective for the cellular metabolism of cyanobacteria. Furthermore, the kinetics indicate that GG accumulation is a prerequisite for adaptation to high salinities, since photosynthesis and growth were restored only after GG was accumulated to significant levels.

The primary function of the GG transporter in saltadapted cells of Synecbocystis 6803 may be the uptake of GG that has leaked out of the cell into the periplasm. Experiments carried out to estimate the $K_{\mathrm{m}}$ value gave evidence that GG is present in the periplasm of saltgrown cells. In these cells a high internal GG level has to be maintained. The avoidance of losses would save carbon and energy for the cells. This presumption is supported by the low activity of the GG uptake compared to the GG synthesis found in Synechocystis 6803. In natural habitats GG should be present only in traces. Significant amounts of extracellular GG may only occur in microbial mats exposed to changing salinities where GG has been detected in natural populations (Stal \& Reed, 1987). Further studies should be carried out to investigate the presence and the function of GG transport in cyanobacterial species with different salt tolerances.

\section{ACKNOWLEDGEMENTS}

This work was partly supported by a grant from the Deutsche Forschungsgemeinschaft, FRG, SFB 305, A13. We thank Thomas J. Buckhout for providing floridoside and Annelise Schmidt for technical assistance.

\section{REFERENCES}

Allen, M. B. \& Arnon, D. I. (1955). Studies on nitrogen-fixing bluegreen algae. I. Growth and nitrogen fixation by Anabaena cylindrica Lemm. Plant Pbysiol 30, 366-372.

Boch, J., Kempf, B. \& Bremer, E. (1994). Osmoregulation in Bacillus subtilis: synthesis of the osmoprotectant glycine betaine from exogenously provided choline. J Bacteriol 176, 5364-5371.

Boos, W., Ehmann, U., Forkl, H., Klein, W., Rimmele, M. \& Postma, P. (1990). Trehalose transport and metabolism in Eschericbia coli. $J$ Bacteriol 172, 3450-3461.

Brown, A. D. (1976). Microbial water stress. Bacteriol Rev 40, 803-846.

Csonka, L. N. \& Hanson, A. D. (1991). Prokaryotic osmoregulation: genetics and physiology. Annu Rev Microbiol 45, 569-606.

Erdmann, N., Berg, C. \& Hagemann, M. (1989). Missing salt adaptation of Microcystis firma (cyanobacterium) in the dark. Arch Hydrobiol 114, 521-530.

Erdmann, N., Fulda, S. \& Hagemann, M. (1992). Glucosylglycerol accumulation during salt acclimation of two unicellular cyanobacteria. J Gen Microbiol 138, 363-368.

Feige, G. B., Gimmler, H., Jeschke, W. D. \& Simonis, W. (1969). Eine Methode zur dünnschichtchromatographischen Auftrennung von ${ }^{14} \mathrm{C}$ - und ${ }^{32} \mathrm{P}$-markierten Stoffwechselprodukten. J Chromatogr $41,80-90$.

Flores, E. \& Schmetterer, G. (1986). Interaction of fructose with the glucose permease of the cyanobacterium Synechocystis sp. strain PCC 6803. J Bacteriol 166, 693-696.

Fulda, S., Hagemann, M. \& Libbert, E. (1990). Release of glucosylglycerol from the cyanobacterium Synechocystis spec. SAG 92.79 by hypoosmotic shock. Arch Microbiol 153, 405-408.

Galinski, E. A. \& Truper, H. G. (1994). Microbial behaviour in saltstressed ecosystems. FEMS Microbiol Rev 15, 95-108.

Giaever, H. M., Styrvold, O. B., Kaasen, I. \& Strøm, A. R. (1988). Biochemical and genetic characterization of osmoregulatory trehalose synthesis in Escherichia coli. J Bacteriol 170, 2841-2849.

Hagemann, M. \& Erdmann, N. (1994). Activation and pathway of glucosylglycerol synthesis in the cyanobacterium Synechocystis sp. PCC 6803. Microbiol 140, 1427-1431.

Hagemann, M. \& Zuther, E. (1992). Selection and characterization of mutants of the cyanobacterium Synechocystis sp. PCC 6803 unable to tolerate high salt concentrations. Arch Microbiol 158, 429-434.

Hagemann, M., Erdmann, N. \& Wittenburg, E. (1987). Synthesis of glucosylglycerol in salt-stressed cells of the cyanobacterium Microcystis firma. Arch Microbiol 148, 275-279.

Hagemann, M., Wölfel, L. \& Krüger, B. (1990). Alterations of protein synthesis in the cyanobacterium Synechocystis sp. PCC 6803 after a salt shock. J Gen Microbiol 136, 1393-1399.

Incharoensadki, A., Takabe, T. \& Akazawa, T. (1986). Effect of betaine on enzyme activity and subunit interaction of ribulose-1,5bisphosphate carboxylase/oxygenase from Apbanotbece balophytica. Plant Pbysiol 81, 1044-1049. 
Joset, F., Buchou, T., Zhang, C.-C. \& Jeanjean, R. (1988). Physiological and genetic analysis of the glucose-fructose permeation system in two Synechocystis species. Arch Microbiol 149, 417-421.

Kirst, G. O. (1990). Salinity tolerance of eukaryotic marine algae. Annu Rev Plant Pbysiol Plant Mol Biol 41, 21-53.

Larsen, P. I., Sydnes, L. K., Landfald, B. \& Strøm, A. R. (1987). Osmoregulation in Eschericbia coli by accumulation of organic osmolytes: betaines, glutamic acid, and trehalose. Arch Microbiol 147, $1-7$.

Lucht, J. M. \& Bremer, E. (1994). Adaptation of Escherichia coli to high osmolarity environments : osmoregulation of the high-affinity glycine betaine transport system ProU. FEMS Microbiol Rev 14, 3-20.

Mi, H., Endo, T., Schreiber, U., Ogawa, T. \& Asada, K. (1994). $\mathrm{NAD}(\mathrm{P}) \mathrm{H}$ dehydrogenase-dependent cyclic electron flow around photosystem I in the cyanobacterium Synechocystis PCC 6803: a study of dark-starved cells and spheroplasts. Plant Cell Pbysiol 35, 163-174.

Moore, D. J., Reed, R. H. \& Stewart, W. D. P. (1987). A glycine betaine transport system in Apbanothece balopbytica and other glycine betaine-synthesising cyanobacteria. Arch Microbiol 147, 399-405.

Perroud, B. \& Le Rudulier, D. (1985). Glycine betaine transport in Escherichia coli: osmotic modulation. J Bacteriol 161, 393-401.

Raddatz, G. (1994). EKI-Programm. In Enzymkinetik, Theorie und Methoden. Edited by $\mathrm{H}$. Bisswanger. Weinheim: $\mathrm{VCH}$ Verlagsgesellschaft.

Reed, R. H. \& Stewart, W. D. P. (1985). Osmotic adjustment and organic solute accumulation in unicellular cyanobacteria from freshwater and marine habitats. Mar Biol 88, 1-9.

Reed, R. H. \& Stewart, W. D. P. (1988). The response of cyanobacteria to salt stress. In Biochemistry of the Algae and Cyanobacteria, vol. 12, pp. 217-231. Edited by L. J. Rogers \& J. R. Gallon. Oxford: Clarendon Press.

Reed, R. H., Warr, S. R. C., Kerby, N. W. \& Stewart, W. D. P. (1986). Osmotic shock-induced release of low molecular weight metabolites from free-living and immobilized cyanobacteria. Enzyme Microb Technol 8, 101-104.

Schmetterer, G. \& Flores, E. (1988). Uptake of fructose by the cyanobacterium Nostoc sp. ATCC 29150. Biocbim Biopbys Acta 942, 33-37.

Schoor, A., Erdmann, N., Effmert, U. \& Mikkat, S. (1995). Determination of the cyanobacterial osmolyte glucosylglycerol by high-performance liquid chromatography. $J$ Chromatogr $A$ 704, 89-97.

Smith, A. J. \& Moore, J. E. (1988). Transport of carbohydrates into cyanobacteria. Methods Enzymol 167, 551-556.

Stal, L. J. \& Reed, R. H. (1987). Low-molecular mass carbohydrate accumulation in cyanobacteria from a marine microbial mat in response to salt. FEMS Microbiol Ecol 45, 305-312.

Styrvold, O. B. \& Strøm, A. R. (1991). Synthesis, accumulation, and excretion of trehalose in osmotically stressed Escherichia coli K-12 strains: influence of amber suppressors and function of the periplasmic trehalase. J Bacteriol 173, 1187-1192.

Tel-Or, E., Spath, S., Packer, L. \& Mehlhorn, R. J. (1986). Carbon13 NMR studies of salt shock-induced carbohydrate turnover in the marine cyanobacterium Agmenellum quadruplicatum. Plant Physiol 82, 646-652.

Wilkinson, G. N. (1961). Statistical estimations of enzyme kinetics. Biochem J 80, 324-332.

Received 21 August 1995; revised 30 November 1995; accepted 13 February 1996. 